\title{
Ioan Slavici şi Vasile Voiculescu: o receptare pastoral-misionară
}

\author{
Bogdan Ioan ANISTOROAEI*
}

\begin{abstract}
The present paper forwards the interpretation from a pastoralmissionary perspective of two writings in the Romanian literature, Popa Tanda by Ioan Slavici and Ciorbă de bolovan by Vasile Voiculescu. The two authors are rooted in Christian morality; moreover, by means of the two writings, each author manages to reach the profound reality of a community which can lose and regain this quality, of the communion which loses its Christological centre, but is able to rediscover it. In the end, both writings suggest that man cannot lose the seed of charisma which restores his side of being in communion, therefore able to rise again. Slavici, a classical author of the Romanian literature, builds his novella in a realistic key, using humour, while Voiculescu writes a storyparable; Voiculescu's story was written in his last stage of creation, the last ten years before the arrest which was shortly followed by his death. The present paper comprises a pastoral-missionary approach of characters, places, and especially events. Moreover, the interpretation relates to the needs of contemporary man, as well as to the problems that a shepherd of souls may encounter in a community.
\end{abstract}

* PhD Candidate, Faculty of Orthodox Theology at „Al. I. Cuza” University in Iași, Romania. 
Key-words: novella, story-parable, morality, community, communion

\section{Introducere}

Ioan Slavici şi Vasile Voiculescu sunt două dintre personalităţile de excepţie ale culturii române. Primul, un clasic al literaturii noastre, şi-a articulat opera literară pe o conştientă dimensiune morală, în nuvelele sale putându-se vorbi de o voce a sa personală care se face auzită prin intermediul diferitelor personaje. Ioan Slavici s-a născut pe 18 ianuarie 1848, anul revoluţiei, trecând la cele veşnice în 1925, pe 17 august. Ultimii cinci ani şi i-a petrecut într-o cumplită suferinţă, generată de ultima arestare, cea de la 1919. Deşi a petrecut mai puţin de un an în temniţă, consecinţele au fost dintre cele mai devastatoare. Receptat ca un trădător, prin opţiunea sa pentru o alianţă cu Austria, în primul război mondial, este arestatt. Avea 71 de ani. Aceasta după ce cunoscuse temniţa, începând cu 1888, „condamnat de către administraţia maghiară pentru că luase apărarea drepturilor politice ale românilor din Transilvania"'. În 1958, la vârsta de 74, Vasile Voiculescu este arestat în contextul orânduirii comuniste; eliberat în 1962, va supravieţui mai puţin de un an. Consecinţele acestui act nedrept de la sfârşitul vieţii celor doi scriitori ar fi unul dintre punctele care-i apropie, în plan biografic. Eminescu a jucat un rol important în viaţa lui Slavici, perioada vieneză a lui Slavici (1869-1874) a însemnat apropierea de

${ }^{1}$ „Ultima parte a vieţii lui Slavici stă sub semnul tragismului, căci scriitorul care militase o viaţă întreagă pentru alianţa României cu Austria, se situează, în timpul primului război mondial, pe aceeaşi poziţie. Ceea ce, dacă din punctul său de vedere era o probă de consecvenţă, din punctul de vedere al intereselor naţionale, gestul echivala cu o trădare. Astfel că, întemniţarea sa la Văcăreşti, în ianuarie 1919, trebuie înţeleasă în acest context. Deşi n-a stat la închisoare mai mult de un an, a suporta, după ce a fost eliberat, oprobiul public, neiertător, ceea ce, pentru un om care a militat o viaţă întreagă în favoarea afirmării naţionale nu putea constitui decât o imensă durere." Pompiliu Marcea, Prefaţă la Ioan Slavici, Popa Tanda, Edit. Ion Creangă, p. 12.

${ }^{2}$ Ibidem. 
şi începutul prieteniei cu Mihai Eminescu. Acesta 1-a îndemnat spre anumite lecturi şi 1-a încurajat să scrie. L-a adus la cenaclul Juniumea şi 1-a determinat să publice în Convorbiri literare.

Nici Voiculescu nu a stat departe de Eminescu, chiar dacă nu au avut cum să se întâlnească, Vasile Voiculescu născându-se în 1884; impactul a fost important. Perioada petrecută în zona Bârladului ca medic de ţară, în perioada primului război a însemnat şi apropierea de Al. Vlahuță, cu cenaclul său literar. Viziunea eminesciană a lui Vlahuţă a avut un rol important în viaţa şi opera lui Voiculescu. Am dat doar câteva elemente legate de cei doi scriitori, înainte de a trece la cele două texte propuse spre analiză într-o cheie pastoralmisionară. Vorbim de Popa Tanda, în cazul primului autor şi de Ciorbă de bolovan, în cazul celui de-al doilea. Nu vom recurge la o analiză comparată, cele două proze vor fi analizate separat.

\section{Popa Tanda - de la discurs la puterea exemplului}

Prin Popa Tanda pătrundem în mentalitatea comunităţii rurale, Slavici însuşi fiind unul dintre scriitorii care a avut, de mic, conştiinţa comunitătiii³. Scrisă în urmă cu 145 de ani, în 1875, a fost cuprinsă în volumul Novele din popor, volum apărut în 1881. Ochiul realist al lui Slavici pătrunde obiectiv în comunităţi iar nararea se face în această cheie a realităţii, umorul fiind o categorie estetică de care Slavici uzează tocmai în vederea evidenţierii realismului său.

Preotul Trandafir, personajul central al nuvelei, „nici doi ani n-a putut să stea în Butucani”" . De remarcat faptul că satul din care este nevoit să plece era un sat cu oameni înstăriţi, cu toate acestea „la pomeni şi la ospețe părintele Trandafir nu mergea bucuros"s. Cusurul acestui personaj, preot de sat, era acela că spunea lucrurilor pe nume.

3 „scriitorul a crescut în mijlocul unei comunităţi largi”, Pompiliu Marcea, Slavici, Edit. Facla, 1978, p. 20.

${ }^{4}$ Ioan Slavici, Proză -Poveşti - Nuvele - Mara, Vol. I, Edit. Cartea Românească, 1980, p. 218.

${ }^{5}$ Ibidem. 
Această caracteristică a sa generează conflictul. Pe de o parte cu satul, pe de alta cu protopopul, or este ştiut că, în mentalitatea acelor vremuri, cu protopopul ,preoţii trebuie să nu facă multă vorbă. Decât vorbele, la protopopi, darurile au mai mult înţeles". Dar preotul nostru îşi avea legea lui: „ce-i drept şi adevărat, nici la dracu nu-i minciună”" Consecinţa imediată a conflictului iscat este aceea că este trimis din satul Butucani, cu oamenii înstăriţi, după cum am menţionat, în satul Sărăceni. „Popă-n Sărăceni? Cine ştie ce vrea să zică popă-n Sărăceni! Dar aşa-i trebuie părintelui Trandafir! Cine vrea să sară peste groapă, arunce-şi mai-nainte desagii peste ea. Părintele Trandafir n-avea însă decât o nevastă şi doi copii. Desagii îi erau deşerţi. Pentru aceasta îi era atât de greu să sară din Butucani la Sărăceni"». Desagii îi erau goli - primul indiciu care face posibilă umplerea ce va urma. Preotul Trandafir trăieşte starea de golire. El ajunge aşadar popă-n Sărăceni. Sărăcia care reiese chiar din primul impact toponimic are o importanţă deosebită în economia vieţii ce va să înceapă. Sărăcia este lipsă, dar este şi plin, este bogăţie, bogăţia unei încă neataşări de o lume fără Dumnezeu. Golul ce-l împresoară e spaţiul fertil al bunului început. Toponimele sunt importante prin însemnătatea lor. Vale - pentru că era un loc închis între munţi, seacă pentru că pârâul e secat în cea mai mare parte a anului. Pe lângă aceste toponime mai apar şi cele patru dealuri cu nume relevante: Râpoasa, Faţa, Gropniţa (pe care e satul) şi Aluniş. Pârâul Răpiţa îi face pe sărăceni, primăvara, în doar câteva ceasuri foarte bogaţi: de apă. Pe Faţa sărăcenii au holdele, doar că „grâul creşte cât palma, păpuşoiul cât cotul”. În această comunitate casele sunt rare, ici colo câte una, ,gardurile sunt de prisos fiindcă n-au ce îngrădi”" ${ }^{10}$. Această stare de fapt are mai multe înţelesuri. Sărăcenii

\footnotetext{
${ }^{6}$ Idem, p. 219.

${ }^{7}$ Ibidem.

${ }^{8}$ Ibidem.

${ }^{9}$ Idem, p. 220.

${ }^{10}$ Ibidem.
} 
nu au gard, nu au încă repere, nu au sinele definit. Poate fi înţeles ca expresie a lipsei dar şi a deschiderii. Fiind lipsiţi de îngrădire ei au vocaţia deschiderii. Un avvă, mergând prin pustiu văzând o chilie a spus: avvo, dă-mi uşa ta!, Ia-o!, a venit răspunsul. Aceasta este capacitatea de a te desface pentru celălalt. Sărăcenii stau în orizontul deschiderii, dar şi al primirii.

În ceea ce priveşte bisericuţa, axul comunităţii creştine, lucrurile nu stau mai bine. În cel mai înalt punct al satului este o ,,alcătuială pe care sărăcenii o numesc biserică" "11. Toate aceste condiţii fac ca Sărăcenii să nu fie un sat fără popă, ci mai degrabă popa lor e fără sat $^{12}$. În acelaşi spectru al golului stă şi faptul că ,încuietorile erau de lemn"13 astfel că „,traista lui se potrivea cu pragul poporenilor"14. Acesta este decorul în care preotul nostru îşi începe activitatea misionar-pastorală. Primul punct surprins de Slavici este liturgic, practic îl găsim pe personaj în prima sa duminică în Sărăceni uimind prin predica sa. Se citise pericopa fiului risipitor, predica fiind pe măsură. Din perspectivă pastoral-misionară, acest act catehetic în cadrul liturgic este o reuşită. Oamenii plecau de-a dreptul încântaţi iar replicile conţineau adevărate encomioane: „Aşa popă n-a mai fost în Sărăceni!”15, ,popă, chiar popă, ca la un sat cinstit”'16, vine răspunsul lui Mitru la observaţia lui Marcu Florii. Dar în Sărăceni cuvântul lipsit de faptă duce la o slăbire a interesului, aşa încât, încetul cu încetul, părintele nostru dă îndărăt cu predicile, nu prea mai avea cui să le ţină.

Desprindem o concluzie de mare importanţă pentru cel ce face

\footnotetext{
${ }^{11}$ Ibidem.
${ }^{13}$ Ibidem.
${ }^{14}$ Ibidem.
${ }^{15}$ Idem, p. 223.
${ }^{16}$ Ibidem.

${ }^{12}$, ,...)era sat cu popă, numai că popa lor totdeauna era popă fără sat. Un lucru singur în felul lui cu Sărăcenii ăştia. Mai că n-a fost încă popă care să fi stat mai mult de trei zile în sărăceni; şi care a stat mai mai multă vreme aici s-a curăţit de păcate.", idem, p. 221. 
misiune, pentru cel ce păstoreşte, anume, faptul că prin şi prin cuvinte slujim, prin cuvinte dăm mărturie despre Cuvânt. Eroul nostru ajunge în acest moment delicat, iar modul în care gestionează acest fapt duce la faptul că oamenii nu mai vin. Preotul are cuvântul - grăirea ca formă de „manifestare intenţionată a unei persoane către alta”"17; mai mult decât atât, pentru că prin puterea şi lucrarea preotului, întărit de puterea şi lucrarea Duhului, comunitatea devine comuniune, ,,cuvântul e vehiculul comuniunii, puntea între persoane ca subiecte"18.

Urmează cea de-a doua etapă în raportul pastoral al părintelui Trandafir cu enoriaşii. Începe a-i căuta el pe aceştia, sfatul nu lipseşte din tactica lui: „Cât e ziua de mare, gura lui nu se mai oprea”, aceasta deoarece ,unde prindea oamenii, acolo îi ţinea la sfaturi”, mai mult, „te omora cu sfatul”"19. Constatând că aşa nu merge, face trecerea spre „ceva mai aspru”20. Astfel, se intră în etapa a treia: batjocura. Aşa se face că s-a ajuns în situaţia nedorită în care oamenii se fereau de el ca de ciumă. Din această etapă părintele Trandafir devine Popa-Tanda: „după atâta tândălitură, oamenii i-au pus numele Popa-Tanda”21. Se constată o greşeală strategică a eroului nostru, mutarea predicii, a cuvântului în stradă în forma greşită a sfatului şi a batjocorii excesive, el pune pe umerii oamenilor, care îşi pierd în ochii lui calitatea de persoane, mai mult decât poate el însuşi duce. Despre gestionarea predicii, în cazul nostru mutată deja în stradă, în comunitate, Sf. Ioan Gură de Aur are cuvinte peremptorii: „să fie înfrântă și limba celui ce predică, pentru a nu depăşi măsura în învinuirile pe care le aduce"22.

${ }^{17}$ Dumitru Stăniloae, Iisus Hristos sau Restaurarea omului, Craiova, Edit. Omniscop, 1993, p. 81.

${ }^{18}$ Ibidem.

${ }^{19}$ Ioan Slavici, op. cit, p. 223.

${ }^{20}$ Idem, p. 224.

${ }^{21}$ Ibidem.

${ }^{22}$ Sf. Ioan Gură de Aur, apud Pr. Costachi Grigoraş, ,...Mergând, învăţaţi toate neamurile!...", Bazele hristologice, apostolice şi patristice ale Cateheticii şi Omileticii, Iaşi, Edit. Trinitas, 2000, p. 228. 
Greşeala vine şi din faptul că ceea ce trebuie să fie o constantă a preotului, vizitarea enoriaşilor, se transformă într-un motiv de gâlceavă. Preotul, cel ce face pastoraţie şi misiune, trebuie să aibă o bună raportare la parohie şi prin perspectiva vizitelor, pe care trebuie să le facă, dar făcând tot posibilul să nu iasă din cuvântul părintelui capadocian ${ }^{23}$.

Urmare a acestor etape ale activităţii sale misionare s-a ajuns la o situaţie de nedorit, după doi ani ,oamenii ajunseseră atâta de sfătoşi şi atâta de batjocoritori, încât ziua întreagă stau grămezi, câteodată la sfat, câteodată la batjocură’’24. Trece şi această limită, ajungând la ocări care-i determină pe sărăceni să se plângă episcopului, acesta dându-i lui dreptate. $\mathrm{Cu}$ trei copii şi o soţie bolnavă, Popa-Tanda are un moment în care pune început bun: se roagă. Momentul este de o tensiune interioară uluitoare, Slavici se dovedeşte şi aici un bun cunoscător al sufletului care ajunge la limită. După expresia autorului, eroul nostru ajunsese în acel moment în care putințele se ating cu neputinţele. În această stare intră în biserică. Modul în care se ajunge la ideea de bază, care face schimbarea porneşte din ceea ce nu ar putea anunţa nimic deosebit, în această privinţă se apropie de N. Gogol, un maestru în a atinge paroxismul trecând prin toate etapele banalităţii. Aşadar, părintele intră în biserică. Ce poate fi mai normal în viaţa unui preot decât intrarea sa în sfântul lăcaş. Dar totuşi ceva e diferit, pentru că dacă până atunci intrase ,precum intră făurarul în făurărie" ${ }^{25}$, de data aceasta ,îl prinse o frică neînțeleasă" ${ }^{26}$. Plângând, părintele reduce întregul său sistem care-l consacrase, vorbăria, la doar patru cuvinte: „Puternice Doamne! Ajută-mă!'”27. El împlineşte,

${ }^{23}$ Despre importanţa ieşirii în parohie, a vizitelor pastorale vorbeşte foarte aplicat Mitropolitul Emilianis Timiadis în Preot, Parohie, Innoire, Bucureşti, Edit. Sofia, 2001. Capitolul 4, Vizitele pastorale este evident în acest sens.

${ }^{24}$ Ioan Slavici, op. cit. p. 223.

${ }^{25}$ Idem, p. 226.

${ }^{26}$ Ibidem.

${ }^{27}$ Ibidem . 
devenind întruchipare a apropierii cu frică şi cu cutremur, îndemnul liturgic pe care până atunci îl nesocotise. Se creează o punte cu primul moment, primul său cuvânt la evanghelia fiului risipitor, pentru că asemenea celui plecat de la sânul tatălui, părintele îşi vine în fire: câţi argaţi ai tatălui meu, devine nu merge... aşa nu merge ${ }^{28}$. În primăvara ce urmează el renaşte. Îşi face casa, ia trestia şi face acoperiş. Recurge la a-şi face gard pentru că nu putea spune la mine acasă pentru că la el era în sat. Simbolic, separarea, gardul poate fi receptat dintr-o altă perspectivă. Am văzut lipsa gardului ca deschidere, acum putem recepta actul acesta exterior ca pe un început de a-şi face cunoscută o identitate; el şi-a venit în sine - e forma identităţii regăsite, pe care părintele o pune în practică. Îngrădirea lui nu limitează, are un sens paradisiac, de afierosire - în identitate redevine partener de dialog, asemenea omului din primordii, care fusese izolat de lumea pe care avea să o cunoască, dar scindat. Şi părintele Trandafir creşte interior, în plan exterior aceasta se vede prin fiecare nouă faptă a sa care face din el un gospodar. Oamenii se iau după el, îi urmează exemplul. Finalul e unul patriarhal - Popa Tanda, în tihna familiei sale, între copiii săi şi copiii copiilor - e o imagine psalmică, nimeni nu-l poate lua în râs cu asemenea bogăţii în bătătură. Trecut prin mai multe stadii ale misiunii şi pastoraţiei, de la cuvântul lipsit de acoperire în faptă, trecut prin stadiile omului care are soluţii pentru alţii, nu şi pentru sinele său scindat, ajunge în final să fie pătruns de harul lui Dumnezeu prin rugăciune - devine om al faptei. Rugăciunea şi fapta fac din el „omul lui Dumnezeu”29.

\section{Vasile Voiculescu - puterea comunităţii în comuniune}

Toposul voiculescian al povestioarei Ciorbă de bolovan este Flămânzii-Vechi, un loc unde fundalul sonor obişnuit era acela al

\footnotetext{
${ }^{28}$ Idem, p. 227.

${ }^{29}$ Idem, p. 234.
} 
scâncetelor de copii şi al vaietului „mamă... mi-e foame” ${ }^{30}$. Toponimul din începutul operei sugerează căutarea, starea omului neîmplinit care are conştiinţa menirii sale. Evanghelic, flămândul şi însetatul, stau sub semnul biruinţei, al fericirii. Satul fusese strămutat, pe locul vechi cocioabele stăteau să fugă, motiv pentru care erau numite Iude, după numele trădătorului. Viclenia şi trădarea sunt stări care pândesc omul în a cărui chip sălăşluieşte vocaţia fericirii, a plinătăţii. În acest loc şi pe un asemenea fundal sonor, într-o dimineaţă, ,din marginea de răsărit” ${ }^{31}$ - semn al aşteptării, a poposit un străin. Este preluat de o ,ciotcă de prunci” ${ }^{2}$ flămânzi. Simbolic, spaţiul foamei e unul al potenţei umplerii, copiii - simbol al primirii mesajului ce le va fi adus. Străinul ia încetul cu încetul, discret, contact cu sătenii. O femeie e acrită că a intrat aşa dintr-o dată, dar Străinul replică, mâhnit, că dacă era uşă bătea şi „,nu intram până ce nu primeam învoire" ${ }^{\prime 3}$. Voiculescu propune în acest context această frumoasă metaforă a uşii, a delicateţii lui Hristos care, iată, stau la uşă şi bat; de va auzi cineva glasul Meu şi va deschide uşa, voi intra la el şi voi cina cu el şi el cu Mine (Apoc. 3, 20). Străinul provoacă cerând ceea ce acolo se pare a nu fi, cere hrană, pentru că ,umblu de mult. Vin de departe. Am isprăvit merindele. N-aş putea găsi aici puţină mâncare? Sunt ostenit şi flămând"34. Râzând, femeia îl alungă. Nu se dă bătut şi merge mai departe dar peste tot îl întâmpină sărăcia, jalea şi amarul. Batjocorit, ajunge la ultima cocioabă unde copiii se hrăneau cu humă. Străinul îi opreşte şi le propune o ciorbă de bolovan. Pregăteşte un bolovan alb, ca de doi pumni - imagine a jertfei aduse spre transfigurare, pe care îl spală - îl trece prin apa schimbării. Încetul cu încetul adună tot ce trebuie: vreascuri, un ceaun, ceapă, cartofi. Pentru fiecare element

\footnotetext{
${ }^{30}$ Vasile Voiculescu, Ciorbă de bolovan, în „Proza”, Edit. Nemira, 2006, p. 479.

${ }^{31}$ Ibidem.

${ }^{32}$ Ibidem .

${ }^{33}$ Idem, p. 480.

${ }^{34}$ Ibidem.
} 
adus de un om al comunităţii are un cuvânt care-i face să capete încredere. Ilinca nu înţelege cum va face, dar răspunsul străinului este că ,asta-i taina mea" ${ }^{35}$. O recurenţă este gestul înălţării ochilor „plini de rugăciune la cer”36. Pentru că sarea e puţină rosteşte cu copiii rugăciunea Tatăl nostru. Iar pentru cei care nu vor să aducă puţinul care ar fi de folos le aduce aminte unde ţine ceea ce se pare că a uitat. Iar oamenii aduc dintr-un îndemn de dincolo de ei. Ilinca ascultă ce i se spune şi face pentru că este ,,prinsă de puterea pătrunzătoare a străinului'"37. Paginile următoare aduc în prim plan comunitatea care se adună şi contribuie cu câte ceva la cina ce va avea loc: slănină, zarzavaturi, chiar şi blide. La acea masă, ,străinul a slujit pe fiecare cum se cuvine”, „stând în picioare şi alergând de colo colo"38. A sluji cum se cuvine, pe fiecare după a lui nevoie, înţelegem că în primul rând duhovnicească, e o concluzie din perspectivă pastoral-misionară aplicată în orice vreme şi-n orice loc. Totul capătă dimensiunile nunţii din Cana, cu diferenţa pentru firoscosul satului că acolo a fost Hristos şi cârtind aduce în discuţie că acolo totul a fost repede, astfel, încetul cu încetul, sătui, oamenii micşorau meritul şi cazna străinului. Străinul le propune această minune pentru fiecare zi, piatra şi ceaunul rămân, suficient pentru ca organizarea lor să dea roade, să facă minuni. Miezul adevăratei minuni va fi în acea comunitate „dragostea celor ce se strâng ca să se ajute singuri şi unul pe altul, cu puţinul pe care-1 are fiecare..." 39 . Comunitatea ar fi vrut o „minune neaoşă, nu de asta omenească"40. Străinul este constant, gândul său pentru comunitate, element de bază în pastoraţie şi misiune este acela că mai mare minune este aceea de înmănunchea ,toate dragostele la un loc şi să faci din ele o singură putere biruitoare peste necazuri şi

\footnotetext{
${ }^{35}$ Idem, p. 483.

${ }^{36}$ Ibidem .

${ }^{37}$ Idem, p. 484.

${ }^{38}$ Idem, p. 488.

${ }^{39}$ Idem, p. 489.

${ }^{40}$ Ibidem.
} 
sărăcii”" ${ }^{4}$. În acest context al respingerii cuvântului viu doar Ilinca ia aminte, e altfel, are în ea ceva din aşezarea celui de-al zecelea lepros care se întoarce. ,Îl cunoştea de undeva şi nu ştia de unde să-l ia. Şi se zbuciuma să-şi aducă aminte. Îl văzuse de câteva ori. Dar unde? În vis! În copilărie! La o durere mare?"42 S-a năpustit spre biserica din sat, întâmpinată de un bătrânel care o întreabă dacă Domnul este tot sus la ei. În final, printre chipurile de la altar Îl recunoaşte pe Străinul care îi vizitase. Preotul zilelor noastre are de rezolvat şi această problemă care nu iese din registrul pastoral-misionar, de a supraveghea construirea şi pictarea bisericii în noile comunităţi. Oare întotdeauna recunoaştem în chipul pictat chipul pe care-L ştim din copilărie, sau dintr-o mare durere? Iconic vorbind, pasajele dedicate recunoaşterii Mântuitorului sunt fascinante prin detaliile iconografice: roşul şi albastrul veşmintelor, surâsul blând „din zugrăveala mohorâtă’" ${ }^{\prime 3}$. Şi în chipul lui recunoaşte chipurile din sat, chipuri care coborau cu toate în ,inima de lumină a lui Iisus”"4. Dar nu doar cei vii, ci şi cei morţi se perindau prin faţa ei, adică în „,chipul Domnului ca să se aşeze toţi, neamestecaţi, dar înfrăţiţi în uriaşa încăpere a inimii Lui" ${ }^{45}$. Tot în registrul pastoral-misionar actual desprindem conţinutul teologic, dogmatic al povestirii, toate aceste cunoştinţe netrebuind să lipsească din conştiinţa preotului zilelor noastre pentru ca cei păstoriţi să se închine în duh şi în adevăr ${ }^{46}$. Doar un exemplu în acest sens, secvenţa epistolară din Coloseni, 1, 15-16 o regăsim metaforic încriptată într-o observaţie ca cea de la pagina 492, a ediţiei folosite: „Ş̦tia acum, fără

\footnotetext{
${ }^{41}$ Ibidem.

${ }^{42}$ Idem, p. 490.

${ }^{43}$ Idem, p. 491.

${ }^{44}$ Ibidem.

${ }^{45}$ Idem, p. 492.

${ }^{46}$ „Dar vine ceasul şi acum este, când adevăraţii închinători se vor închina Tatălui în duh şi în adevăr, că şi Tatăl astfel de închinători îşi doreşte. Duh este Dumnezeu şi cei ce I se închină trebuie să i se închine în duh şi în adevăr" (Ioan 4, 23-24).
} 
să priceapă, cum că Hristos este lumea toată, cea de pe pământ şi cea de sub pământ, topită de la începutul la sfârşitul veacului, fără să-L schimbe, fără să-L adauge, fără să-I poată copleşi nemăsurata, străluminata Lui înălţime şi adâncime". Mângâiată de mâna ce iese din icoană, primeşte cuvântul de a nu se teme şi de a-I purta crucea până la sfârşit. Două idei de substanţă pentru cel ce face misiune şi pastoraţie. Acest gest şi aceste cuvinte zidesc în femeie o pace ,pe care nimic nu mai avea să o zdruncine" ${ }^{47}$.

Ca şi concluzie pastoral-misionară desprindem din aceste fragmente dragostea ca fundament al comuniunii, în fond, inima curată ce se cere a fi zidită în păstor, în cadrul liturgic - cultic, precum şi în rugăciunea permanentă personală. Pr. prof. Ion Buga, în lucrarea Pastorala - Calea preotului, atinge această problemă fundamentală a pastoraţiei, iubirea. „Secretul marilor înfăptuiri dintotdeauna a stat în iubire. Universul întreg şi mai ales omul, sunt rodul iubirii lui Dumnezeu, Care iubeşte lumea (In. 3, 16), o încălzeşte cu drag la sânul Său şi o conduce spre împlinirea ei - fericirea veşnică în razele iubirii Lui" ${ }^{48}$. În parabola voiculesciană metafora inimii de lumină este tocmai acest sân la care se încălzeşte lumea toată, lume pe care o regăsim în povestire prin înşiruirea viilor şi a morţilor. Revenind la slujirea pastorală, rămânând în perimetrul volumului părintelui Buga, întărim printr-un alt cuvânt care arată raportul pastoraţie-iubire: „Preoţia, fiind opera cea mai mare, slujirea cea mai înaltă din toate câte sunt pe lume, trebuie să fie temeluită pe iubire mai mult decât orice altă lucrare omenească" ${ }^{49}$.

În finalul povestirii, registrul se schimbă brusc, naratorul fiind trezit din somn de amicul Sava. Încearcă mai multe finaluri pentru povestirea sa, ce s-a petrecut cu femeia pe care nimeni nu o credea,

\footnotetext{
${ }^{47}$ Idem, p. 493.

${ }^{48}$ Pr. prof. Ion Buga, Pastorala - Calea preotului, Edit. Sfântul Gheorghe Vechi, 1999, p. 112.

${ }^{49}$ Ibidem.
} 
care devine nebuna lui Hristos. După câteva variante de final, ieşite din nota vizionară, naratorul e cumva nemângâiat că a pierdut încheierea, „cea descoperită, nu cea închipuită” ${ }^{5_{0}}$. În cele din urmă se resemnează, poate că finalul „nici nu este pe lumea asta" ${ }^{\circ 1}$. Am putea constata că aşa stau lucrurile, că finalul ţine de veşnicie, de urcuşul fără de sfârşit la care comunitatea e chemată iar preotul are menirea de a aduna în jurul lui, prin dragoste şi în numele lui Hristos, pe cei vii şi pe cei adormiţi, permanent pomeniţi. Metafora inimii de lumină, atotcuprinzătoare, la care face referire doctorul fără de arginţi Vasile Voiculescu rămâne axul liturgic al oricărei comunităţi, ea este adevărata minune care face ca prin vinele preotului şi a enoriaşilor să circule sângele vieţii vii.

\section{Bibliografie:}

1. Buga, Ion, Pastorala - Calea preotului, Edit. Sfântul Gheorghe Vechi, 1999.

2. Grigoraş, Costachi, ,Mergând, invățaţi toate neamurile!...”, Bazele hristologice, apostolice şi patristice ale Cateheticii şi Omileticii, Iaşi, Edit. Trinitas, 2000.

3. Marcea, Pompiliu, Slavici, Bucureşti, Edit. Facla, 1978.

4. Slavici, Ioan, Popa Tanda, cu o prefaţă de Pompiliu Marcea, Bucureşti, Edit. Ion Creangă.

5. Slavici, Ioan, Proză - Poveşti - Nuvele - Mara, Vol. I, Edit. Cartea Românească, 1980.

6. Stăniloae, Dumitru, Iisus Hristos sau Restaurarea omului, Craiova, Edit. Omniscop, 1993.

7. Timiadis, Emilianis, Preot, Parohie, Înnoire, București, Edit. Sofia, 2001.

8. Voiculescu, Vasile, Proza, Edit. Nemira, 2006.

\footnotetext{
${ }^{50}$ Ioan Slavici, op. cit., p. 495.

${ }^{51}$ Ibidem.
} 
